\section{An empirical assessment of the Healthy Early Childhood Program in Rio Grande do Sul State, Brazil}

\author{
Uma avaliação empírica do Programa Primeira \\ Infância Melhor no Estado do Rio Grande do Sul, \\ Brasil
}
Una evaluación empírica del programa Primera Infancia Mejor en el estado de Río Grande do Sul, Brasil

Felipe Garcia Ribeiro 1

Gisele Braun 1

André Carraro 1

Gibran da Silva Teixeira 2

Denise Petrucci Gigante 1

doi: 10.1590/0102-311X00027917

\section{Correspondence}

G.S. Teixiera

Universidade Federal do Rio Grande.

Av. Itália, km 08, Rio Grande, RS 96200-400, Brasil.

tgibran@hotmail.com

(Healthly Early Childhood Program) on infant mortality in the state of Rio Grande do Sul, Brazil. We estimate infant mortality's counterfactual trajectories using the differences-in-differences approach, combined with the use of longitudinal data for all municipalities in the state of Rio Grande do Sul. Our main result is that the program reduced the number of deaths caused by external causes. The length of exposure to the program seems to potentiate the effects. For the number of deaths by general causes, there is no evidence of impact. Our findings are consistent with the nature of the program that aims to improve adults care with children. The Healthly Early Childhood Program is effective in reducing the number of avoidable deaths in infants.

Infant Mortality; Primary Health Care; Program Evaluation
1 Universidade Federal de Pelotas, Pelotas, Brasil.
2 Universidade Federal do Rio Grande, Rio Grande, Brasil. 


\section{Introduction}

Over the last twenty years there has been a significant improvement in Brazilian health indicators ${ }^{1}$. In particular, the reduction of infant mortality 1,2,3 stands out. Even though economic and social progress are usually the first causes associated with improved health indicators, it is possible that public policies are exerting a significant influence in changing the health scenario 4 . For this reason, this study investigates the effects of the Healthy Early Childhood Program (Primeira Infância Melhor PIM, in Portuguese) program on the mortality indicators of infants under one year old, in Rio Grande do Sul State, Brazil.

Opportunities for play, exploration, and learning are necessary for a child's healthy and creative development 5 . The recognition of what the child knows how to do better, the affectivity and the connection between parents and the child generate a family and social environment that are important for children's development. At the same time, this connection stimulates the cerebral, emotional and behavioral development of the child with reflexes for his adulthood 6,7.

Despite this importance, the presence of poverty and the social vulnerability of the family might result in less interaction between parents and children, less affective connection and less care with child development. Estimates based on the Index of Early Childhood Development show that 36.8\% of children aged 3 to 4 years from low- and middle-income countries do not reach the basic development of cognitive and socioemotional skills 8 . Evidence shows that a child raised in a poor family knows fewer words than a child from a wealthier family ${ }^{9}$, and that poor families are less likely to take their children to health centers 10 . On account of this reality, public policies for early childhood intervention based on home visits are classified as effective policies that promote a successful strategy to reduce the damages caused by poverty and social vulnerability 5 .

Given that PIM is a home visit-based program, in this study, we assess PIM's effects on mortality indicators caused by general causes, diarrhea and external causes in the municipalities of Rio Grande do Sul. We investigate whether the program has been successful in reducing infant mortality in the municipalities covered by the program. In addition, we perform a cost-effectiveness analysis.

\section{Healthy Early Childhood Program}

Created as a social policy in Rio Grande do Sul in 2003, PIM became State Law n. 12,544 on July 3, 2006 11. Its methodology is based on the Cuban Educate Your Child Program, coordinated by the Latin American Reference Center for Early Childhood Education (CELEP), from whom PIM initially received support for its implementation. PIM can be defined as a transversal action that aims to promote the full development of children in early childhood, respecting skills formation at each stage. The goal of promoting the development of cognitive and socioemotional abilities is based on literature 5,6. Specifically, the objectives of the program take into account the literature on: (i) the positive role of the cognitive and socioemotional abilities in school performance and later in life; (ii) the consequences of unequal promotion of these abilities compared to other children; and (iii) the importance of the family environment for the development of these abilities 12,13,14,15,16.

In general, the different programs of early childhood interventions are child-, parent- or jointfocused 17. PIM is focused on both the family and the child, using entertaining activities as a tool to strengthen the families' abilities to educate and care for their children. Anther PIM objective is to develop actions to prevent infant mortality.

The actual "treatment" given by the program consists of monitoring families with pregnant women or children from 0 to 6 years of age, for the stimulation and adoption of good care practices, using entertaining activities and always focusing on the child's interaction with the family and the community. This monitoring practice is conducted through two types of weekly visits: at the family or community level.

In the former, the program is directed at the participating families that have pregnant women or children under 3 years of age. In the latter, which occur in public places, it is directed at the families that have enrolled in the program and have children under 6 years of age. In these weekly visits, the 
visitors promote playful activities that stimulate family and community relationships with children, with the aim of achieving their full development.

The elaboration of care plans for the individuals, together with the health agents, social workers and educators of the municipalities, is part of program's actions. The program also seeks, in an intense way, to identify women in early stages of pregnancy and children in situations of social vulnerability and at risk of violence to join the program. Regarding newly pregnant women, PIM aims to find them before the first prenatal visit in the first quarter of pregnancy. PIM provides them with orientation to promote breastfeeding, healthy nutrition, general and health care, besides actions with the health system, with the intention of reducing maternal and infant mortality and improving citizenship.

PIM began its work covering 9\% of the 496 municipalities in Rio Grande do Sul in 2003. After a rapid expansion, the program reached $45 \%$ of municipalities in 2006. Since 2010 , the program has been covering half of the municipalities statewide. However, the percentage of children benefiting is relatively low, with population coverage at less than $6.59 \%$ of the total children aged between 0 and 6 years.

\section{Methodology}

We used an ecological and longitudinal approach through the use of municipalities' panel data, which are transverse cohorts repeated over time. In the present study, data from the 496 municipalities of Rio Grande do Sul are repeated between the years 2006 and 2012. For identification of the program's impact and the existence of possible heterogeneous effects as a function of length of exposition, we explore the different entry times of each municipality into the program, as well as respective length of exposure to the program. This type of methodology has been applied for an evaluation of the Family Health Program (FHP) 18.

Outcomes analyzed include mortality rates caused by general causes, mortality rates caused by diarrhea, and mortality rates caused by external causes. All results accounted for children under one year, and they are measured per thousand children under one year old.

PIM's effectiveness is measured for each municipality by year, according to the following four classifications: (i) the municipality did not join PIM, in year t; (ii) the municipality joined PIM from one to three years ago, starting in year $t$; (iii) the municipality joined PIM from four to six years ago, starting in year t; and (iv) the municipality joined PIM seven years ago or more, starting in year $t$.

Based upon previous studies about the effects of health policies $4,18,19$, we selected variables that could confound the identification of effects of the program on mortality rates. These variables include demographic characteristics (proportion of men, youngsters from 0 to 14 years of age, adults from 15 to 29 years, adults from 20 to 59 and elderly people 60 years old or more) and gross domestic product (GDP) per capita at municipality level (constant prices, considering 2000 as the base year). Moreover, at a per capita of one thousand inhabitants, total number of schools, teachers, physicians, nurses, hospital beds, hospitals and out-patient clinics were added. Regarding vaccination coverage, we included information for the Bacillus Calmette-Guérin (BCG) vaccine, which prevents tuberculosis, yellow fever, poliomyelitis, triple bacterial (DTP) and first dose against rotavirus .

We also performed regression analysis stratifyng the sample according to FHP coverage: low coverage and high coverage. The first group was formed by municipalities with FHP coverage up to the median of mean of FHP coverage during the sample years (2006-2012). The second group was formed by municipalities with FHP mean coverage above the median.

FHP is a nationwide health program, which is also based on family visits and focused on poor populations, and has had effects on child mortality 4 . Although the FHP has a focus on a population that is also targeted by PIM, the two programs have distinct natures. FHP develops activities that encourage families to vaccinate children, guide pregnant women about the importance of prenatal care, guide about personal and household hygiene, among other activities. The expansion of primary care and family health provided by FHP's expansion of FHP enabled women and children to have greater access to health services 20 . Increased access to health has brought positive results for children's health, improved prenatal care, decreased infectious disease rates and reduced infant mortality 
18,19,21,22. Therefore, it is possible that there are intereactions between FHP and PIM that might affect infant mortality.

We add a variable to allow for the possibility of different linear tendency across municipalities. Furthermore, we include dichotomous variables for each year considered in the analysis. They are used to capture effects of shocks throughout the time, which might affect mortality in the same way across municipalities 18 .

The assessment of the program's impact is divided into unadjusted and adjusted analyses. The unadjusted analysis does not include any covariate while the adjusted analysis is performed using all above described covariates. The adjusted analysis is similar to the method of differences-in-differences and their derivations. The method of differences-in-differences is widely used in economics, particularly for research related to public policy evaluations. This methodological approach has already been used in epidemiological studies and its validity for health studies is being discussed by epidemiological scholars $23,24,25,26$. The estimated errors are corrected by clusters of municipalities as recommended in the empirical approach of differences-in-differences 27 . The regressions were weighted by municipalities population size, also following previous studies with mortality data aggregated at the level of municipalities and states 18,28 .

\section{Data}

The main dataset was obtained from the DATASUS (Brazilian Health Informatics Department), which is a database organized by the Brazilian Ministry of Health. It encompasses all secondary healthcare episodes in the public sector, including the number of deaths by age and by cause ${ }^{29}$, for each municipality in Rio Grande do Sul. Moreover, the database provides information regarding health facilities and workforce (hospitals and physicians, for example). FHP's data about vaccination coverage and municipal coverage were also obtained from DATASUS. Provision of educational services was extracted from the School Censuses (Instituto Nacional de Estudos e Pesquisas Educacionais Anísio Teixeira. Microdados para download. http://portal.inep.gov.br/basica-levantamentos-acessar, accessed on 29/Jun/2016) and from the Department of Education of Rio Grande do Sul. All information regarding PIM and municipalities' participation in the program were obtained from the Department of Health of Rio Grande do Sul. The municipality-level GDP per capita data was obtained from the Fundação de Economia e Estatística do Rio Grande do Sul (Economics and Statistics Foundation of Rio Grande do Sul). Limited data availability for all municipalities has constrained the analysis for the period of 2006 to 2012 .

\section{Data analysis}

We estimate a group of multivariate equations using the linear estimation method with fixed effects for municipalities. The estimated equation for the adjusted analysis is the following:

$$
y_{m t}=\alpha+\beta_{1} \mathrm{PIM}_{m t}^{1 a 3}+\beta_{2} \mathrm{PIM}_{m t}^{4 a 6}+\beta_{3} \mathrm{PIM}_{m t}^{7+}+\gamma X_{m t}+\theta_{m}+\lambda_{t}+\pi_{m} t+\varepsilon_{m t}
$$

The variable $y_{\mathrm{mt}}$ represents the children mortality outcome for municipality $m$ in year $t$. The PIM $\mathrm{M}_{m t}^{1 \mathrm{a} 3}$, $\mathrm{PIM}_{m t}^{4 a 6}$ and $\mathrm{PIM}_{m t}^{7+}$, are binary variables that represent the municipality $m$ 's length of exposure to the program in year $t$ ( 1 to 3 years, 4 to 6 years, 7 or more years, respectively). Municipalities that have not joined PIM are the baseline for comparison (242 municipalities). The vector $X_{m t}$ represents the covariates for demographic characteristics, supply of education services, supply of healthcare services, and FHP coverage in municipality $m$ in year $t$. The $\theta_{m}$ controls for the non-observable and time-invariant characteristics of municipality $m$. The $\lambda_{t}$ are binary variables for the periods of the analysis and $\pi_{m} t$ is the term of linear tendency, which might be different for the municipalities. Finally, $\varepsilon_{m t}$ is an idiosyncratic error term.

The above defined econometric specification for the adjusted analysis of the program is similar to one already used in literature to estimate FHP's effects on mortality indicators 18 . Such specifications probably generate the best counterfactuals for assessment of the PIM, given that it isolates the effects of time and of other factors capable of affecting infant mortality, which was not done in some 
previous studies evaluating FHP 4,19. One example of such a factor is the variation of political management captured by different provision levels of education and healthcare services. Another example is economic crises during certain periods that may affect mortality rates. All analysis was performed using Stata software (StataCorp LP, College Station, USA).

\section{Results}

Table 1 presents the descriptive statistics - mean and standard deviation (SD) - of mortality rates for infants under one year old by cause of death, for all municipalities from 2006 to 2012. Descriptive statistics of the covariates and of the measures of exposure to PIM are also present in this Table. During the sample period, by a descriptive statistics analysis (without statistical test for trends), the mortality rate by external causes and by diarrhea have been consistent, except in 2011, when rates decreased .

Table 1

Descriptive statistics.

\begin{tabular}{|c|c|c|c|c|c|c|c|}
\hline Variables & $\begin{array}{c}2006 \\
\text { Mean (SD) }\end{array}$ & $\begin{array}{c}2007 \\
\text { Mean (SD) }\end{array}$ & $\begin{array}{c}2008 \\
\text { Mean (SD) }\end{array}$ & $\begin{array}{c}2009 \\
\text { Mean (SD) }\end{array}$ & $\begin{array}{c}2010 \\
\text { Mean (SD) }\end{array}$ & $\begin{array}{c}2011 \\
\text { Mean (SD) }\end{array}$ & $\begin{array}{c}2012 \\
\text { Mean (SD) }\end{array}$ \\
\hline \multicolumn{8}{|l|}{ Mortality rates $<1$ year $(/ 1,000$} \\
\hline \multicolumn{8}{|l|}{ population) } \\
\hline General causes & $9.98(5.59)$ & $11.87(7.13)$ & $12.94(7.56)$ & $12.09(7.49)$ & $11.66(7.27)$ & $12.02(8.41)$ & $11.33(7.65)$ \\
\hline Diarrhea & $0.10(0.31)$ & $0.09(0.73)$ & $0.09(0.52)$ & $0.09(0.59)$ & $0.07(0.83)$ & $0.04(0.44)$ & $0.09(0.51)$ \\
\hline External causes & $0.47(1.15)$ & $0.68(1.63)$ & $0.51(1.23)$ & $0.56(1.54)$ & $0.56(1.64)$ & $0.45(1.27)$ & $0.41(1.26)$ \\
\hline \multicolumn{8}{|l|}{ PIM coverage (\%) } \\
\hline Not & 70.42 (45.69) & $55.13(49.79)$ & $55.93(49.70)$ & $54.12(49.88)$ & $52.31(49.99)$ & $49.29(50.04)$ & $48.69(50.03)$ \\
\hline $1-3$ years & $29.37(45.60)$ & $35.62(47.93)$ & $25.15(43.43)$ & $17.71(38.21)$ & $4.82(21.46)$ & $8.05(27.23)$ & $6.64(24.92)$ \\
\hline 4-6 years & $0.00(0.00)$ & $9.05(28.72)$ & $18.71(39.04)$ & $27.97(44.93)$ & $34.00(47.42)$ & $24.35(42.96)$ & $17.30(37.87)$ \\
\hline $7+$ years & $0.00(0.00)$ & $0.00(0.00)$ & $0.00(0.00)$ & $0.00(0.00)$ & $8.85(28.14)$ & $18.10(38.55)$ & $27.16(44.52)$ \\
\hline \multicolumn{8}{|l|}{ Demographic caracteristics (\%) } \\
\hline Men & $49.03(1.39)$ & $48.98(1.46)$ & $48.98(1.47)$ & $48.97(1.49)$ & $48.67(1.39)$ & $48.67(1.39)$ & $48.67(1.39)$ \\
\hline People 0-14 years & $26.07(2.39)$ & $23.00(2.38)$ & $22.46(2.38)$ & $21.90(2.36)$ & $20.86(2.31)$ & $20.86(2.31)$ & $20.86(2.31)$ \\
\hline People $15-29$ years & $25.50(1.57)$ & $25.43(1.54)$ & $25.33(1.53)$ & $25.21(1.55)$ & $24.68(1.80)$ & $24.68(1.80)$ & $24.68(1.80)$ \\
\hline People 30-59 years & $38.06(1.57)$ & $39.36(1.56)$ & $39.63(1.57)$ & $39.92(1.59)$ & $40.80(1.40)$ & $40.80(1.39)$ & $40.80(1.39)$ \\
\hline People 60+ years & $10.37(2.20)$ & $12.20(2.67)$ & $12.57(2.76)$ & $12.97(2.85)$ & $13.65(2.70)$ & $13.65(2.70)$ & $13.65(2.70)$ \\
\hline \multicolumn{8}{|l|}{ Vaccination coverage (\%) } \\
\hline BCG & $102.02(15.64)$ & $100.24(15.81)$ & $98.76(17.65)$ & $98.93(17.58)$ & $96.76(20.62)$ & $101.34(21.33)$ & $101.34(22.92)$ \\
\hline Yellow fever & $5.49(22.07)$ & $6.13(24.62)$ & $6.74(21.27)$ & $32.01(36.33)$ & $30.80(31.78)$ & $37.03(35.92)$ & $51.12(35.76)$ \\
\hline Poliomyelitis & $99.77(14.52)$ & $100.85(15.65)$ & $94.03(14.01)$ & $96.11(14.88)$ & $93.31(15.53)$ & $96.01(16.48)$ & $90.37(17.49)$ \\
\hline Triple bacterial & $100.17(14.21)$ & $100.78(15.58)$ & $93.74(14.08)$ & $95.55(14.91)$ & $93.03(15.81)$ & $95.58(16.48)$ & $86.65(17.75)$ \\
\hline 1st Rotavirus dose & $45.59(13.49)$ & $79.43(16.55)$ & $81.53(14.10)$ & $84.83(14.46)$ & $83.47(16.43)$ & $85.33(17.77)$ & $85.13(17.27)$ \\
\hline \multicolumn{8}{|l|}{ Supply of services $(/ 1,000$} \\
\hline \multicolumn{8}{|l|}{ population) } \\
\hline Hospital & $0.03(0.05)$ & $0.03(0.05)$ & $0.03(0.04)$ & $0.03(0.04)$ & $0.03(0.04)$ & $0.03(0.04)$ & $0.03(0.04)$ \\
\hline Clinics & $0.08(0.15)$ & $0.08(0.16)$ & $0.08(0.15)$ & $0.09(0.15)$ & $0.09(0.16)$ & $0.08(0.15)$ & $0.08(0.15)$ \\
\hline Hospital beds & $2.75(1.92)$ & $2.73(1.89)$ & $2.80(1.83)$ & $2.78(1.82)$ & $2.84(1.86)$ & $2.83(1.88)$ & $2.86(1.83)$ \\
\hline Physicians & $1.73(1.11)$ & $1.47(1.01)$ & $0.58(0.39)$ & $0.64(0.41)$ & $0.68(0.40)$ & $0.72(0.43)$ & $0.78(0.46)$ \\
\hline Nurses & $0.54(0.38)$ & $0.53(0.37)$ & $0.58(0.39)$ & $0.64(0.41)$ & $0.68(0.40)$ & $0.72(0.43)$ & $0.78(0.46)$ \\
\hline Schools & $0.94(0.60)$ & $0.98(0.62)$ & $0.92(0.50)$ & $0.91(0.47)$ & $0.93(0.44)$ & $0.93(0.43)$ & $0.94(0.42)$ \\
\hline Teachers & $14.19(3.23)$ & $11.68(2.88)$ & $11.97(2.51)$ & $11.73(2.42)$ & $12.02(2.33)$ & $12.24(2.40)$ & $12.56(2.48)$ \\
\hline \multicolumn{8}{|l|}{ Other characteristics } \\
\hline GDP (per capita, prices from & 8535.95 & 9012.03 & 9572.08 & 9559.71 & 10488.37 & 10250.15 & 10217.30 \\
\hline BRL 2,000) & $(6052.31)$ & (5919.02) & (6598.03) & $(6094.87)$ & $(6721.91)$ & (5864.63) & $(5639.26)$ \\
\hline FHP coverage per 1,000 & 272.41 & 301.40 & $324.22(325.15)$ & $332.76(310.73)$ & 343.34 & $340.72(306.71)$ & $349.17(304.64)$ \\
\hline population & $(283.13)$ & (311.03) & & & $(337.47)$ & & \\
\hline
\end{tabular}

FHP: Family Health Program; PIM: Healthy Early Childhood Program; SD: standard deviation.

Source: elaborated by the authors.

Note: each variable was weighted by municipalities' population size, except the PIM coverage. 
In 2006, 29\% of municipalities were covered by PIM from one to three years (PIM 1 to 3 years). In the following year, this number increased to 35\%. By 2012, 17\% of municipalities were covered from four to six years (PIM 4 to 6 years), and 27\% of municipalities were covered by PIM for at least seven years (PIM 7+ years). This indicates that municipalities increasingly adhered to the program during this period.

Table 2 shows the results of both the unadjusted and adjusted analyses. There are three panels of results. The first one is for full sample (all municipalities) results, and the two others are for stratyfing analysis resulsts. For the full sample, there is no significant estimated coefficient in the unadjusted analyses at the 5\% level of statistical significance. From the adjusted specification, i.e., from the approach of the differences-in-differences, for those municipalities which had been covered by the program for 7 or more years, PIM's estimated effect was of $-0.68(-1.34 ;-0.01)$ deaths caused by external causes per one thousand children. The coefficient is statistically significant at $5 \%$. Considering the 10\% significance level, the estimated effect of PIM for municipalities that are in the program from four to six years was $-0.45(-0.98$; 0.08$)$ deaths caused by external causes per thousand children. For mortalities by general causes and diarrhea, the estimated coefficients in the adjusted analyses were all negative, as expected, but not statistically significant at the $5 \%$ level. However, considering the significance level at 10\%, the effect of PIM in the municipalities that are in the program from 1 to 3 years on deaths caused by diarrhea was statistically significant, and its magnitude was $-0.10(-0.22$; 0.02) deaths caused by diarrhea per thousand children.

Table 2

PIM's effects on infant mortality rates.

\begin{tabular}{|c|c|c|c|c|c|c|}
\hline \multirow[t]{2}{*}{ Years of PIM } & \multicolumn{2}{|c|}{ General causes } & \multicolumn{2}{|c|}{ Diarrhea } & \multicolumn{2}{|c|}{ External causes } \\
\hline & Unadjusted & Adjusted & Unadjusted & Adjusted & Unadjusted & Adjusted \\
\hline \multicolumn{7}{|l|}{$\begin{array}{l}\text { Full sample (all } \\
\text { municipalities) }\end{array}$} \\
\hline $1-3$ & $0.17(-1.09 ; 1.42)$ & $-1.00(-2.95 ; 0.94)$ & $-0.01(-0.08 ; 0.06)$ & $-0.11(-0.22 ; 0.02)$ & $-0.07(-0.30 ; 0.17)$ & $-0.25(-0.62 ; 0.13)$ \\
\hline $4-6$ & $1.20(-0.15 ; 2.55)$ & $-0.66(-3.09 ; 1.77)$ & $0.00(-0.07 ; 0.08)$ & $-0.06(-0.24 ; 0.12)$ & $-0.09(-0.41 ; 0.22)$ & $-0.45(-0.98 ; 0.08)$ \\
\hline 7 or + & $0.31(-1.17 ; 1.79)$ & $-1.10(-4.36 ; 2.16)$ & $-0.02(-0.10 ; 0.06)$ & $-0.01(-0.24 ; 0.22)$ & $-0.26(-0.63 ; 0.10)$ & $-0.68 *(-1.34 ;-0.02)$ \\
\hline $\mathrm{N}$ & 3,472 & 3,472 & 3,472 & 3,472 & 3,472 & 3,472 \\
\hline \multicolumn{7}{|c|}{$\begin{array}{l}\text { FHP coverage (below } \\
\text { the median) }\end{array}$} \\
\hline $1-3$ & $0.03(-1.33 ; 1.38)$ & $-0.72(-2.86 ; 1.41)$ & $-0.01(-0.08 ; 0.06)$ & $-0.06(-0.18 ; 0.07)$ & $-0.09(-0.34 ; 0.16)$ & $-0.33(-0.72 ; 0.06)$ \\
\hline $4-6$ & $1.26(-0.18 ; 2.70)$ & $0.09(-2.60 ; 2.78)$ & $-0.01(-0.09 ; 0.06)$ & $-0.00(-.020 ; 0.19)$ & $-0.13(-0.46 ; 0.21)$ & $-0.55(-1.14 ; 0.04)$ \\
\hline 7 or + & $0.35(-1.23 ; 1.94)$ & $-0.47(-4.25 ; 3.30)$ & $-0.04(-0.12 ; 0.05)$ & $0.04(-0.20 ; 0.27)$ & $-0.29(-0.68 ; 0.10)$ & $-0.77 *(-1.52 ;-0.03)$ \\
\hline $\mathrm{N}$ & 1,736 & 1,736 & 1,736 & 1,736 & 1,736 & 1,736 \\
\hline \multicolumn{7}{|c|}{$\begin{array}{l}\text { FHP coverage (above } \\
\text { the median) }\end{array}$} \\
\hline $1-3$ & $0.95(-3.06 ; 4.96)$ & $-0.93(-6.69 ; 4.83)$ & $-0.05(-0.21 ; 0.10)$ & $-0.29(-0.70 ; 0.11)$ & $0.26(-0.68 ; 1.20)$ & $-0.01(-1.28 ; 1.26)$ \\
\hline $4-6$ & $0.76(-3.69 ; 5.23)$ & $-6.36(-15.51 ; 2.80)$ & $0.15(-0.20 ; 0.51)$ & $-0.52(-1.19 ; 0.14)$ & $0.27(-0.72 ; 1.26)$ & $-0.30(-2.23 ; 1.63)$ \\
\hline 7 or + & $-0.82(-6.74 ; 5.10)$ & $-10.54(-23.09 ; 2.01)$ & $0.16(-0.32 ; 0.64)$ & $-0.46(-1.36 ; 0.45)$ & $-0.29(-1.45 ; 0.87)$ & $-1.00(-3.88 ; 1.88)$ \\
\hline $\mathrm{N}$ & 1,736 & 1,736 & 1,736 & 1,736 & 1,736 & 1,736 \\
\hline
\end{tabular}

FHP: Family Health Program; PIM: Healthy Early Childhood Program;

Note: covariates are \% men, \% people 0 to 14, \% people 15 to 29,\% people 20 to 59, \% people 60+ years, vaccination coverage (BCG, yellow fever, poliomyelitis, triple bacterial coverage, and rotavirus), hospitals, outpatient clinics, hospital beds, physicians, nurses, schools, teachers, gross domestic product per capita, year dummies and municipality-specific linear tendency. The sample median for all years of FHP's coverage is 881.66 per 1,000 habitants.

$* p<0.05$. 
Table 2 also shows that there is evidence that for municipalities up to the median of FHP coverage, PIM reduces infant mortality caused by external causes. Actually, the effect estimated (-0.77; $-1.51 ;-0.03)$ is even stronger than that we observed in the sample of all municipalities. However, for the sample of municipalities above the median of FHP coverage there are no statistically significant estimated coefficients.

\section{Discussion}

This study used the differences in differences method by exploring the entry year and the time of exposure to PIM in 496 municipalities in Rio Grande do Sul, in order to capture the causal effect of exposure to the program on infant mortality caused by diarrhea, general causes and external causes.

It is worth saying why the analyses are constrained to health indicators for infants. First, the attention the program provides to pregnant women should give positive results in the very first year of life. Second, at home visits are only offered to families with pregnant women and children under three years old. For families with older children, the program offers activities at the community level. Therefore, younger children receive a more intense "treatment" as the direct interaction of PIM community agents with the family, which is possibly a better type of intervention in terms of follow-up and expansion of the children's care than less personalized monitoring at the community level. Taking all these reasons into account, we believe that children under one year of age are the fraction of the population that with the most to benefit from PIM.

Of the results obtained, the most significant reveals that PIM reduces by -0.68 (statistical significance at 5\%) deaths by external causes per 1,000 children in municipalities with an exposure time equal to or greater than seven years. Early childhood intervention is not restricted to provision of health care services and nutritional status. There is a growing importance given to the role of the family environment and the degree of encouragement children receive at home as an instrument for the prevention of child abuse and neglect.

PIM and FHP overlap in public served (possibly, families in situation of economic and social vulnerability). As documented in the literature, FHP provided greater access for families to health services that contribute to the prevention of problems associated with child mortality. In this sense, the result obtained from the stratified analysis, the stronger effect of PIM in the municipalities with less coverage of FHP, reveals that PIM may have had the same effects of FHP in those municipalities with less coverage of the second program. However, it is worth emphasizing that nobody is suggesting that PIM should substitute FHP. We are only documenting the positive effects that PIM exerts in reducing infant mortality, in the specific case of external causes, in localities lacking greater FHP coverage.

As already mentioned, PIM is based on family-focused action visits that stimulate cognitive development, explore the relationship of affection between parents and children, and develop good practices that promote child development. In this sense, the obtained result of infant mortality reduction caused by external causes indicates that the program acts to reduce deaths caused by accidents that could be avoided if the caregiver provided greater attention to the child. The evidence obtained suggests the program is successful in promoting better care within the family environment.

This result is statistically significant for municipalities exposed to the program for seven or more years. The time of existence of the program in the municipalities seems to be fundamental for result to materialize. This may be revealing the greater mastery of the technology of operationalization of the program by the agents responsible and involved (managers, visitors, etc.) in the municipalities (learning by doing). In addition, in municipalities where the program has been operationg longer, it is possible that families will also participate longer. Although our study focuses on the mortality of children under one year old, it is possible that, due to older children, families that had already participated in the program benefited from the recommendations of care and good practices.

For programs similar to PIM in other countries, exposure time of families to activities seems to play an important role as well. In the Philippines, the best-performing children spent at least 17 months in the Early Childhood Care and Development Program 30. In Bolivia, the results of the Integral Child Development Project are also stronger the longer the family stays in the program 17. 
However, in both programs the outcomes analyzed are not associated with infant mortality, but rather on anthropometric and motor development indicators.

When we compare our results with those in the literature that discusses effects of family - or community - oriented programs on mortality, especially with FHP evaluations, which have very similar methodology to that implemented in this study 18, we verify that there is no evidence of FHP's effects on children's deaths caused by external causes. We postulate that three factors might explain such differences: (i) they are different programs with different groups of people targeted (FHP has other objectives and methods and has a larger public target); (ii) different periods of time (the existent evaluations for FHP refer to outcomes from the last decade of the past century); and (iii) the state of Rio Grande do Sul has a level of socioeconomic development that is different than that of Brazil in general.

On the other hand, there is evidence that FHP has reduced deaths from general causes and infectious diseases for children. The present research did not find statistically significant (at 5\%) PIM effect (on infant mortality caused by general causes and diarrhea), although there is a significant (at 10\%) impact for diarrhea. This result may be due to two facts. First, Brazil has shown improvements in the coverage of vaccinations and in the incentive to breastfeeding 2 . Second, the country has also advanced in terms of access to basic sanitation during the last few decades 31 . These developments have had a positive impact on infant mortality prevention. This study controlled PIM's impact to vaccination coverage and availability of medical services in the municipalities. However, it was not possible to control for the effect of increased breastfeeding. As PIM reaches a relatively small fraction of children in terms of the total number of municipalities, it is possible that PIM's effect is dispersed within the effects caused by these social advances.

Even recognizing the possibility that other factors may have slightly affected the reduction on mortality rate, it is possible to carry out a cost-effective exercise of the program. For that purpose, the cost of the program was calculated by disability-adjusted life years (DALY).

From coordination of the program, it was obtained that PIM's per capita cost was BRL 886.76 (BRL 446.76 paid by municipalities and BRL 440.00 by the state) in 2014. Applying a 3\% discount rate per year, the total cost of the program in 2012 was BRL 49,775,245.55 (obtained by the product of the cost per capita and total number of children from 0 to 6 years and pregnant women attended, 59,550 people in 2012).

Using the impact of -0.68 deaths by external causes per thousand children in municipalities with 7 or more years of exposure to the PIM, it was estimated that 42.15 deaths of children younger than one year old in these municipalities in 2012 (obtained by the product between -0.68 and the number of children of these municipalities divided by one thousand) were prevented. Given that life expectancy in Rio Grande do Sul was 76.63 years in 2012 (IBGE. http://www.ibge.gov.br/home/estatis tica/populacao/projecao_da_populacao/2013/default_tab.shtm, accessed on 04/Jul/2017), the PIM's DALY was 3,230.46 (product of 42.15 lives saved and 76.63 years of life expectancy at birth). Thus, it is estimated that PIM's cost per DALY was BRL 15,408.10 in 2012.

Following a recommendation from the WHO 32, which compares the value of DALY to triple the per capita GDP of Rio Grande do Sul in 2012 (BRL 77,598.00) (Fundação de Economia e Estatística. http://feedados.fee.tche.br/feedados/, accessed on 04/Jul/2017), PIM emerges as a cost-effective program. Also, since the cost per DALY is lower than the per capita GDP (BRL 25,866.00), it is highly cost-effective, according to references from WHO.

Regarding this comparison of PIM with GDP-related thresholds, however, it is necessary to highlight the criticisms found in the literature that refer to the fact that many programs may be below the per capita GDP threshold and that per capita GDP per se may not adequately represent society's desire to fund programs, in addition to disregarding budget constraints 33 .

We performed the same exercise, but considering PIM's estimated impact at the $10 \%$ statistical significance level. As mentioned in the results section, the estimated effect on deaths by external causes was 0.45 per thousand children in those municipalities where PIM had been operating from 4 to 6 years; moreover, the program had the effect of reducing deaths from diarrhea by -0.10 per thousand children in those municipalities with PIM from 1 to 3 years. With such information and the same calculation procedure, the program presented an even lower DALY cost: BRL 12,261.03. Obviously, with a larger number of lives saved, PIM, which was already highly cost-effective without considering the effects at $10 \%$, remains. 


\section{Limitations}

Because it is a non-experimental evaluation, this study is subject to the classic problems of evaluation impact 34,35 . The selection of municipalities to participate in the program was not random nor observable. It might have been determined by characteristics that make municipalities different in terms of outcomes and other characteristics tendencies. For example, it is possible that the program was first implemented in municipalities with higher mortality rates, worse health care services in general, and more poor people. Table 3 reveals that in fact the municipalities that belong to PIM present, year by year, during the sample period, worse averages in terms of mortality rates and per capita GDP than those municipalities that are not covered by PIM. Therefore, the comparison between infant mortality indicators of municipalities covered by PIM with those municipalities not covered might not measure the exact impact of the program, which would weaken the cost-effectiveness analysis of the public policy.

To overcome the problem of not having an experimental study to be evaluated, we need to trust the assumptions of the difference-in-difference's methodology. In particular, we assume the existence of parallel trends or parallel growths of mortality indicators between the municipalities that joined and the municipalities that did not join PIM, if there was no PIM to join, for assessing the existence of causal relation between the program and the analyzed outcomes. In this way, we rely on the fact that the set of control variables used in the adjusted analyses, which is very similar to those already tested and used in literature 18 , give enough confidence to our program's impact estimation.

Another important limitation of this paper is that, unlike FHP, PIM has a lower scope and a higher level of targeting. Given that availability of health indicators is merely at the level of municipalities, the aggregate of the municipalities' mortality indicators may not capture the effects of the program properly. In other words, considering that the group of program's beneficiaries is small within the population of the municipality, the aggregated data at this level may not reliably capture the effects of the program at the individual level of those benefited by the program. This might explain why we have relatively few statistically significant results and high p-values.

Also, it is worth noting that the evaluation of the program in terms of its other objectives, which are the development of the cognitive and socioemotional abilities, is unfeasible since there is no reliable information, to the best of our knowledge, that associate children health and children development for PIM and non-PIM covered children. Finally, regarding the results of mortality rate caused by diarrhea, it would be interesting to include in the adjusted analyses some covariate that captures population access to sanitation and to safe drinking water, which are important characteristics of

Table 3

Annual average gross domestic product (GDP) per capita and Infant mortality rates of Healthy Early Childhood Program (PIM) and non-PIM municipalities.

\begin{tabular}{|c|c|c|c|c|c|}
\hline \multirow[t]{2}{*}{ Year } & \multirow[t]{2}{*}{$\begin{array}{c}\text { Number of } \\
\text { Municipalities }\end{array}$} & \multicolumn{2}{|c|}{ GDP per capita * (BRL) } & \multicolumn{2}{|c|}{$\begin{array}{c}\text { Mortality }<1 \text { year per } 1,000 \\
\text { population }\end{array}$} \\
\hline & & PIM & Not PIM & PIM & Not PIM \\
\hline 2006 & 222 & 7 & 7,698 & 9.8 & 7.8 \\
\hline 2007 & 218 & 7,319 & 8,356 & 13.1 & 10.0 \\
\hline 2008 & 227 & 7,552 & 8,587 & 13.7 & 11.0 \\
\hline 2009 & 236 & 7,436 & 8,578 & 11.1 & 11.9 \\
\hline 2010 & 251 & 8,129 & 9,346 & 11.0 & 9.1 \\
\hline 2011 & 254 & 8,349 & 9,495 & 11.2 & 12.4 \\
\hline 2012 & 254 & 8,099 & 9,665 & 12.8 & 8.3 \\
\hline
\end{tabular}

Source: Brazilian Health Informatics Department; Economic and Statistics Foundation, Rio Grande do Sul State, and elaboration by the authors.

* The GDP per capita is calculated at constant prices (considering 2000 as the base year). 
infrastructure of the municipalities for the control of diarrhea and other illnesses 36 . In the meantime, the existing data regarding sanitation for the Brazilian municipalities, which is detailed by the National System on Information About Sanitation has several missing values for each year of the study 37 . Therefore, the inclusion of these variables would cause the loss of many observations for performance of the analyses. However, we rely on the fact that the municipalities' GDP per capita is correlated with infrastructure. Therefore, we rely on the fact that the inclusion of GDP among the covariates might mitigate this problem.

Finally, internationally successful programs have at least one feature in common: visitors are trained by professionals with degrees 17. It is possible that differences in visitors' qualification may be associated with program performance.

The municipalities are responsible for recruiting the visitors in PIM, which implies that workers are hired under various work regimes (formal workers, statuaries, scholarship students, etc.). According to data obtained from the program's management, only $8.5 \%$ of the visitors had completed higher education in the year of 2012. However, when aggregating the number of visitors with incomplete higher education, this percentage rises to $43.2 \%$. It is noteworthy that there are practically no visitors with low level of schooling: only $2.7 \%$. Despite the possible importance of the visitor's schooling for the quality of the service provided, it was not possible to control the differences between the qualifications of the visitors in the municipalities in our analysis. Further research can explore this issue.

\section{Conclusions}

The debate on the best structure for a social policy is quite intense in Brazil and often confront the evaluation between more focused policies and more universal policies 38,39. Universal policies may have a wider appeal for service, but sometimes it is possible that a more focused policy may be the first step towards universalisation. This may be the case for PIM. In this sense, the evaluation of regionallevel and highly targeting programs may be essential for the promotion of equality in the access to health care as well as for the development of capabilities and fundamental skills for individuals social and economic development.

The obtained estimates of PIM's effects on reducing deaths caused by external causes, in children younger than one year old, indicate that the program can be effective to promote a better level of population health and to collaborate for the attainment of the millennium goals established for the region.

Future PIM evaluations must go deeper into research synergies with other social programs, which has already been done for FHP 19. Can other solution programs enhance PIM's effects? In countries with development levels that are similar to Brazil, which usually have many poverty reduction programs and social policies being simultaneously implemented, both at national as well as regional levels, the issue of the synergies of public policies is paramount for the debate around the evaluation of its results. 


\section{Contributors}

F. G. Ribeiro, G. Braun and A. Carraro participated in the construction, discussion, analysis of the results and writing of the article. G. S. Teixeira contributed to the discussion, analysis of the results and writing of the article. D. P. Gigante participated in the analysis of the results and writing of the article.

\section{Acknowledgments}

F. G. Ribeiro thanks CNPq for the financial support.

\section{References}

1. Gragnolati M, Lindelow M, Couttolenc B. Twenty Years of health system reform in brazil: an assessment of the Sistema Único de Saúde. Washington DC: World Bank Publications; 2013.

2. Victora CG, Barreto ML, Carmo Leal M, Monteiro CA, Schimidt MI, Paim J, et al. Health conditions and health-policy innovations in Brazil: the way forward. Lancet 2011; 377:2042-53.

3. Volpe FM, Abrantes MM, Capanema FD, Chaves JG. The impact of changing health indicators on infant mortality rates in Brazil, 2000 and 2005. Rev Panam Salud Pública 2009; 26:478-84.

4. Aquino R, de Oliveira NF, Barreto ML. Impact of the Family Health Program on infant mortality in Brazilian municipalities. Am J Public Health 2009; 99:87-93.

5. Hartinger SM, Lanata CF, Hattendorf J, Wolf J, Gil AI, Obando MO, et al. Impact of a child stimulation intervention on early child development in rural Peru: a cluster randomised trial using a reciprocal control design. J Epidemiol Community Health 2017; 71:217-24.

6. Hertzman C, Boyce T. How experience gets under the skin to create gradients in developmental health. Annu Rev Public Health 2010; 31:329-47.

7. Irwin LG, Siddiqi A, Hertzman G. Early child development: a powerful equalizer. Vancouver: Human Early Learning Partnership; 2007.

8. McCoy DC, Peet ED, Ezzati M, Danaei G, Black MM, Sudfeld CR, et al. Early childhood developmental status in low-and middle-income countries: national, regional, and global prevalence estimates using predictive modeling. PLoS Med 2016; 13:e1002034.

9. Berlinski S, Schady N. Os primeiros anos: o bem-estar infantil e o papel das políticas públicas. Washington DC: Inter-American Development Bank; 2016.

10. McCartney K, Dearing E, Taylor BA, Bub KL. Quality child care supports the achievement of low-income children: direct and indirect pathways through caregiving and the home environment. J Appl Dev Psychol 2007; 28:411-26.

11. Secretaria de Saúde do Estado do Rio Grande do Sul. O que é. PIM: Primeira Infância Melhor. http://www.pim.saude.rs.gov.br/v2/opim/o-que-e/ (accessed on 09/Aug/2015).

12. Conti G, Heckman JJ. Economics of child wellbeing. In: Ben-Arieh A, Casas F, Frønes I, Korbin JE, editors. Handbook of child well-being. Theories, methods and policies in global perspective. Dordrecht: Springer; 2014. p. 363401.

13. Cunha F, Heckman J. The technology of skill formation. Am Econ Rev 2007; 97:31-47.

14. Cunha F, Heckman JJ. Formulating, identifying and estimating the technology of cognitive and noncognitive skill formation. J Hum Resour 2008; 43:738-82. 
15. Cunha F, Heckman JJ. The economics and psychology of inequality and human development. J Eur Econ Assoc 2009; 7:320-64.

16. Currie J, Almond D. Human capital development before age five. In: Card D, Ashenfelter O, editors. Handbook of labor economics. v. 4. San Diego/Amsterdam: Elsevier; 2011; p. 1315-486.

17. Baker-Henningham H, López Bóo F. Early childhood stimulation interventions in developing countries: a comprehensive literature review. Washington DC: Inter-American Development Bank; 2010.

18. Rocha R, Soares RR. Evaluating the impact of community-based health interventions: evidence from Brazil's Family Health Program. Health Econ 2010; 19 Suppl 1:126-58.

19. Guanais FC. The combined effects of the expansion of primary health care and conditional cash transfers on infant mortality in Brazil, 1998-2010. Am J Public Health 2013; 103:2000-6.

20. Ceccon R, Bueno ALM, Hesler LZ, Kirsten KS Portes VM, Viecili PRN. Mortalidade infantil e Saúde da Família nas unidades da Federação brasileira, 1998-2008. Cad Saúde Colet (Rio J.) 2014: 22:177-83.

21. Victora CG, Aquino EML, Leal MC, Monteiro CA, Barros FC, Szwarcwald CL. Maternal and child health in Brazil: progress and challenges. Lancet 2011; 377:1863-76.

22. Macink J, Guanis FC, Fátima M, Souza M. Evaluation of the impact of the Family Health Program on infant mortality in Brazil, 19902002. J Epidemiol Community Health 2006; 60:13-9.

23. Basu S, Rehkopf DH, Siddiqi A, Glymour MM, Kawachi I. Health behaviors, mental health, and health care utilization among single mothers after welfare reforms in the 1990s. Am J Epidemiol 2016; 183:531-8.

24. Hawkins SS, Baum CF. Invited commentary: an interdisciplinary approach for policy evaluation. Am J Epidemiol 2016; 183:539-41.

25. Craig P, Cooper C, Gunnell D, Haw S, Lawson K, Macintyre S, et al. Using natural experiments to evaluate population health interventions: new Medical Research Council guidance. J Epidemiol Community Health 2012; 66:1182-6.

26. Rudolph KE, Stuart EA, Vernick JS, Webster DW. Association between Connecticut's permit-to-purchase handgun law and homicides. Am J Public Health 2015; 105:e49-54.
27. Bertrand M, Duflo E, Mullainathan S. How much should we trust differences-in-differences estimates? Quarterly Journal of Economics 2004; 119:249-75.

28. Ruhm CJ. Recessions, healthy no more? J Health Econ 2015; 42:17-28.

29. Queiroz BL, Lima EC, Freire FH, Gonzaga MR. Adult mortality estimates for small areas in Brazil, 1980-2010: a methodological approach. Lancet 2013; 381 Special Issue:S120.

30. Armecin G, Behrman JR, Ghuman S, Gultiano S, King EM, Lee N. Early childhood development through an integrated program: evidence from the Philippines. Washington DC: World Bank Publications; 2006. (World Bank Policy Research Working Paper, 3922-IE).

31. Instituto de Pesquisa Econômica Aplicada. V relatório nacional de acompanhamento dos Objetivos de Desenvolvimento do Milênio. Brasília: Instituto de Pesquisa Econômica Aplicada; 2014.

32. World Health Organization. Choosing interventions that are cost effective. http://www. who.int/choice/en/ (accessed on 04/Jul/2017).

33. Marseille E, Larson B, Kazi DS, Kahn JG, Rosen S. Thresholds for the cost-effectiveness of interventions: alternative approaches. Bull World Health Organ 2015; 93:118-24

34. Dehejia RH, Wahba S. Causal effects in nonexperimental studies: reevaluating the evaluation of training programs. J Am Stat Assoc 1999; 94:1053-62.

35. Ravallion M. The mystery of the vanishing benefits: an introduction to impact evaluation. World Bank Econ Rev 2001; 15:115-40.

36. Zhang J. The impact of water quality on health: Evidence from the drinking water infrastructure program in rural China. J Health Econ 2012; 31:122-34.

37. Ministério das Cidades. Sistema Nacional de Informações Sobre Saneamento. http://www. snis.gov.br/ (accessed on 09/Jun/2016).

38. Giovanella L, Escorel S, Lobato LVC, Noronha JC, Carvalho AI. Políticas e sistema de saúde no Brasil. Rio de Janeiro: Editora Fiocruz; 2012.

39. Kerstenetzky CL. Políticas sociais: focalização ou universalização. Brazilian Journal of Political Economy 2006; 26:564-74. 


\section{Resumo}

Investigamos o efeito de um programa de atenção primária de base familiar, o Programa Primeira Infância Melhor, sobre a mortalidade infantil no Estado do Rio Grande do Sul, Brasil. Estimamos as trajetórias contrafactuais da mortalidade infantil, usando a técnica das diferenças nas diferenças, combinada com o uso de dados longitudinais para todos os municípios do Estado do Rio Grande do Sul. O principal resultado é que o programa reduziu o número de óbitos por causas externas. O tempo de exposição ao programa parece potencializar os efeitos. Não há evidências de impacto sobre o número de óbitos por causas gerais. Nossos achados são compatíveis com a natureza do programa, que procura melhorar a saúde tanto dos adultos quanto das crianças. O Programa Primeira Infância Melhor mostra eficácia na redução do número de mortes evitáveis em lactentes.

Mortalidade Infantil; Atenção Primária à Saúde; Avaliação de Programas e Projetos de Saúde

\section{Resumen}

Hemos investigado los efectos de un programa de atención primaria a la salud basado en la familia, denominado Primera Infancia Mejor, sobre la mortalidad infantil en el estado de Río Grande do Sul, Brasil. Estimamos las trayectorias comparativas de la mortalidad infantil, utilizando la técnica diferencias en diferencias, combinándola con el uso de información longitudinal para todos los municipios en el estado de Río Grande do Sul. Nuestro resultado más significativo es que el programa redujo el número de muertes debidas a causas externas. La duración de exposición al programa pareció potenciar sus efectos. Para el número de muertes debidas a causas generales, no hay evidencia de impacto. Nuestros hallazgos son consistentes con la naturaleza del programa, cuyo objetivo es mejorar el cuidado de niños por parte de los adultos. El programa Primera Infancia Mejor es efectivo en la reducción del número evitable de muertes en niños.

Mortalidad Infantil; Atención Primária de Salud; Evaluación de Programas y Proyetos de Salud
Submitted on $19 / \mathrm{Feb} / 2017$

Final version resubmitted on 24/Aug/2017

Approved on 04/Sep/2017 